Max Weber's Construction of Social Theory 


\section{Max Weber's Construction of Social Theory}

\section{Martin Albrow}

St. Martin's Press

New York 
(C) Martin Albrow 1990

All rights reserved. For information, write:

Scholarly and Reference Division,

St. Martin's Press, Inc., 175 Fifth Avenue,

New York, N.Y. 10010

First published in the United States of America in 1990

ISBN 978-0-333-28546-6 ISBN 978-1-349-20879-1 (eBook)

DOI 10.1007/978-1-349-20879-1

Library of Congress Cataloging-in-Publication Data

Albrow, Martin.

Max Weber's construction of social theory / Martin Albrow.

p. $\mathrm{cm}$.

Includes bibliographical references.

1. Weber, Max, 1864-1920. 2. Sociologists-Germany-Biography. 3. Sociology-German-History. I. Title HM22.G3W396 1990

90-33088

301'.092-dc20 
To the memory of Editha Hirschmann 


\section{Contents}

Foreword

$\mathrm{xi}$

Max Weber: A Brief Biography xiii

Time Chart xvi

Introduction 1

PART I THE FORMATION OF WEBER'S WORLD-VIEW

$\begin{array}{ll}\text { Preamble } & 12\end{array}$

1 Religious Faith in an Intellectual's World 13

1.1 Weber's religiosity 14

1.2 The Protestant individual 17

1.3 Meaning in the world 22

1.4 The symmetry of science and religion 25

2 Reason and the Individual: the Kantian Unit 29

2.1 Knowledge of the world 31

2.2 Kant and the unity of the ' $I$ '

2.3 Reason and the moral agent 37

2.4 Weber's individualism 42

3 The Nietzschean Challenge 46

3.1 The assault on Christianity 47

3.2 The sensual philosophy 50

3.3 The influence of Nietzsche on German culture 53

3.4 The Weber-Nietzsche controversy of $1964 \quad 55$

3.5 Nietzschean themes and attitudes in Weber 58

4 The Scientist in Search of Salvation 62

4.1 Understanding Weber's creativity 63 


\section{viii Contents}

4.2 Goethe's demon 66

4.3 Libido and rationality: bridging the dualism 68

4.4 The search for salvation $\quad 71$

4.5 The philosophy of the scientist's life $\quad 74$

5 Towards a Science of Social Reality 78

$\begin{array}{ll}5.1 \text { Cultural heritage } & 78\end{array}$

5.2 Political and religious value commitments 80

5.3 The 'social problem' 83

5.4 Historical and social research $\quad 87$

5.5 A world of facts 90

\section{PART II CONSTRUCTING AN EMPIRICAL} SOCIAL SCIENCE

Preamble

6 The Scholarly and Plemical Context 97

6.1 Weber's contemporaries $\quad 97$

6.2 Controversies on methods 100

6.3 Weber's achievement 103

6.4 Deflecting Marx 106

6.5 Transcending Hegel 109

7 The Meaning of Rationality 114

$\begin{array}{lll}7.1 & \text { Rationality as idea } & 114\end{array}$

$\begin{array}{lll}7.2 & \text { Rationality as logic } & 117\end{array}$

$\begin{array}{lll}7.3 & \text { Rationality as calculation } & 119\end{array}$

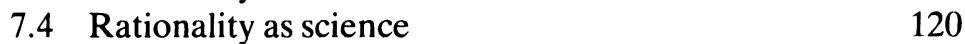

$\begin{array}{lll}7.5 & \text { Rationality as action } & 122\end{array}$

7.6 Rationality as consciousness 124

7.7 Rationality as structure 126

$\begin{array}{lll}7.8 & \text { Irrationality } & 129\end{array}$

7.9 Conflicts of rationality 131

8 From Premises to Constructs: Modelling Social Life 135 Preamble 135

8.1 The most elementary unit of analysis 135

8.2 The types of action 140

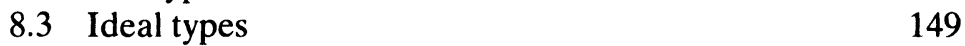

8.4 Rationality in ideal-type construction 154 
9 The Structure of Collective Action 158

9.1 The social relationship 158

9.2 Legitimacy 161

9.3 Power and authority 165

9.4 Groups 168

9.5 Charisma 171

9.6 Morality, obedience and democracy 173

10 The Historical Development of Rationality 177

Preamble $\quad 177$

10.1 Formal and material rationality 178

10.2 The growth of rationality 181

10.3 The boundaries of rationality 186

10.4 Ideas as explanatory factors 189

10.5 Rationality as a force 192

PART III EXPLORATIONS IN WEBERIAN SOCIAL THEORY

Preamble 198

11 Understanding and Social Structure 199

11.1 Human agency 199

11.2 The meaning of understanding 202

11.3 Immediate and motivational understanding 204

11.4 Whose meaning? 208

11.5 Structures of meaning 213

11.6 Facticity and the limits of understanding 218

11.7 Power and compromise 223

12 The Empirical Study of Values 227

Preamble $\quad 227$

12.1 The spirit of the age 227

12.2 The nature of values 230

12.3 Values and the sociological categories 234

12.4 Values and the rationalisation process 237

12.5 Values and the scientist 242

13 Society and the Market 247

13.1 A vocabulary for groups 248

13.2 Collective concepts 251 
$\mathbf{x}$ Contents

13.3 Marx's idea of the social 254

13.4 Weber's analysis of the social 256

13.5 The market 260

13.6 The place of society 267

Conclusion: From Social Theory to Sociology 271

1 Collapse of consensus 271

2 Weber's empirical project 275

3 Social facts 277

4 Reflexivity 279

5 Voice of the twentieth century 281

6 The retrieval of sociology 286

$\begin{array}{ll}\text { References } & 290\end{array}$

Index of Names 298

Index of Subjects $\quad 302$ 


\section{Foreword}

Thirty years ago, almost to the day, I was sitting in the British Council Library in Cologne, completing my reading of Marianne Weber's biography of her husband. It had been a laborious task, chosen as a way of learning German and understanding Weber at the same time. It also took up the generous spare time allowed by the school which employed me as an English language assistant.

It was a way of developing an interest which had been fired in Cambridge by a course on the History of Historiography given by Brian Wormald, whose lectures tantalisingly stopped short of treating the last items on his book list, which happened to be on Max Weber.

I went to the London School of Economics after Germany to begin work on Max Weber's idea of rationality under Morris Ginsberg's supervision. He took the view that this was too narrow a subject for a $\mathrm{PhD}$ and that the idea of rationality tout court was more appropriate. That was somewhat discouraging and I left without completing my thesis.

But in some sense Ginsberg was right. Weber cannot be understood except through an appreciation of the idea which became his driving force, his demon, namely rationality. This book represents my acquiescence to that insight after many years of trying to understand its implications, challenge it or simply ignore it.

Had this book been completed earlier I would not now be able to agree with what it would have said. To that extent a decade or two of delay has been beneficial. But in that time my intellectual debts have mounted alarmingly, so that there is no possibility of acknowledging all the useful discussions I have enjoyed. Only the most notable are mentioned here.

Norbert Elias was simultaneously sceptical, challenging and enormously kind in my early lecturing days in Leicester; Stanislav 


\section{xii Foreword}

Andreski gave enthusiastic support in Reading; while Paul Halmos in Cardiff gave great encouragement. Since then I have enjoyed the stimulating friendships of Anton Zijderveld, Horst Helle and Johannes Weiss, each in his own way having a unique insight into Weber and always ready to share it.

In 1973-4, at the Max Weber Institute in Munich, I had the privilege of many discussions with Johannes Winckelmann who had already forgotten more about Weber than I shall ever know. Gert Schmidt was very helpful to me at that time, as was Constance Rottländer who first gave me an insight into Weber's economics. I hope it is also not too late at this stage to thank the Leverhulme Foundation for its support during that year.

As befits those who shared student days, Tony Giddens and I have always found snooker more interesting than Max Weber when we have been together, and I can only express my appreciation that he has given support at times when it was most needed and has assisted greatly in commenting and making suggestions which have proved beneficial in cutting an unwieldy document down to size. Jem Thomas gave the same first draft a thorough Weberian vetting and I am grateful to him for doing that necessary task. Chris Harris has been extraordinarily generous with his time and inspired me to make those unpalatable changes which turn a text written for myself into one which a reader can find useful. Paul Atkinson made helpful comments on Chapter 11. Liz King has, apart from assisting me in editing International Sociology, found time to prepare the word-processed text with her usual extraordinary speed and meticulousness. To all these people my particular thanks are due.

Above all I need to express my deep gratitude to my wife Susan Owen (Economic Adviser in HM Treasury), formerly Lecturer in Economics at University College, Cardiff, who shared with me the last throes of that institution before its enforced merger, made sure that my priorities were right and morale high and, at the same time, coped marvellously with demanding changes in her own work. Without her, this book would not have been written.

The dedication fulfils a promise made a good ten years ago to someone who had listened to lectures by Rickert and Jaspers, and took into her life's work the lesson that patients are people. 


\section{Max Weber: a Brief Biography}

Max Weber was born on 21 April 1864 in the German town of Erfurt. His father was a lawyer and member of a family of prosperous textile manufacturers. His mother's family placed a high value on education. She was a religious person with an active social conscience.

The Weber family moved to Berlin in 1869 where his father became a member of the German Reichstag as a National Liberal. Max received a classical education and went on to study law at university. He did his military training and practised as a lawyer in Berlin until 1893.

He lived in a period which, with the benefit of hindsight, we can see as leading to the catastrophe of the First World War. The great European powers struggled for world mastery. Their societies were transformed by the emergence of the class of industrial workers. Karl Marx inspired an international working-class movement, while state leaders tried to pacify the demands of the masses with social legislation and to win their allegiance in the international conflict.

It was also a period of value crisis. The Christian world view was challenged by natural science on the one hand and by the glorification of power and freedom for self-expression on the other. Darwin, Nietzsche and Freud became the mentors of the younger generation.

Weber responded to these conflicts and challenges by holding fast to the values of German high culture, to the spirit of Kant and Goethe, at the same time as committing himself to a heroic ideal of intellectual integrity and service to the nation state. 
It was the early period of establishing institutionalised social and economic research for policy purposes. He obtained his academic qualifications by studying the history of law and the ancient world. But his social awareness drew him to the Association for Social Policy.

While working as a lawyer he completed in 1892 a major research project on the social and economic conditions of the Prussian peasantry. His academic reputation grew and in 1894 he was called to a Chair of Economics in Freiburg, from where he moved to a similar position in Heidelberg in 1896.

His fame grew as he stated in the starkest possible terms the conflicts which were inherent in the simultaneous pursuit of national security and economic liberalism. He seemed to have glowing possibilities for careers both in politics and in academic life. But following the death of his father in 1897 Weber fell into a depression and nervous illness.

The tensions in Weber's personality have been the subject of prolonged speculation. He wrote a lengthy self-analysis (unfortunately destroyed) and sought the help of his friend, the philosopher and psychiatrist, Karl Jaspers. Those inner conflicts are frequently referred to in the great biography which Weber's wife, Marianne, published after his death.

He had married in 1893. Marianne was a second generation cousin, a formidable intellect who became a prominent leader of German feminism, surviving him until 1953. She idolised her husband, but it was a marriage of the mind and daily companionship and he at least sought sexual fulfilment in other relationships.

Weber recovered gradually from his illness. He gave up his teaching position in 1903. He travelled frequently in Europe and in 1904 spent a stimulating four months in the United States. His intellectual interests shifted. He worked on the religious basis of human rationality and on the development of Western capitalism. He began to write on the philosophical implications of empirical social science. He became well known as a political commentator.

The years from 1903 to 1920 were marked by a stream of writing which continues to be a treasury of ideas for later scholars. He wrote on topics as various as the Russian Revolution and the sociology of music, the religion of China and the development of the city, industrial psychology and bureaucratic structure. They culminated in his conceptual framework for sociology which was 
linked to his enormous study of the relations between the economy and society.

Although he gave up teaching Weber maintained an intense involvement in academic life. He was in constant contact with the leading scholars of his time and he and Marianne kept open house in Heidelberg for young and old alike.

As a journal editor he turned the Archive for Social Science and Social Policy into the major forum for applied social research. He played the leading part in the debates on value-freedom which took place in the Association for Social Policy between 1909 and 1913. He worked strenuously to help found the German Sociological Society in 1910.

When the First World War broke out in 1914 he committed himself fully to the German cause. He served as an officer administering military hospitals but after leaving the service in the latter part of the war he wrote numerous articles criticising its conduct.

At the end of the war and immediately after Weber was prodigiously active in numerous directions. He joined and campaigned for the German Democratic Party. He wrote and spoke against socialist revolution. He was a member of the German peace delegation at Versailles. He wrote and spoke against right-wing violence.

Finally he took another permanent Chair in Munich in 1919. He lectured in overflowing lecture theatres on basic concepts in sociology, on economic history and on political science. He had laboured for years on his great works, the three-volume Sociology of Religion and the two-volume Economy and Society. He prepared them for publication, dedicating them to his wife and his mother respectively, who had just died. He was never to see them in print. He died of pneumonia on 14 June 1920. 


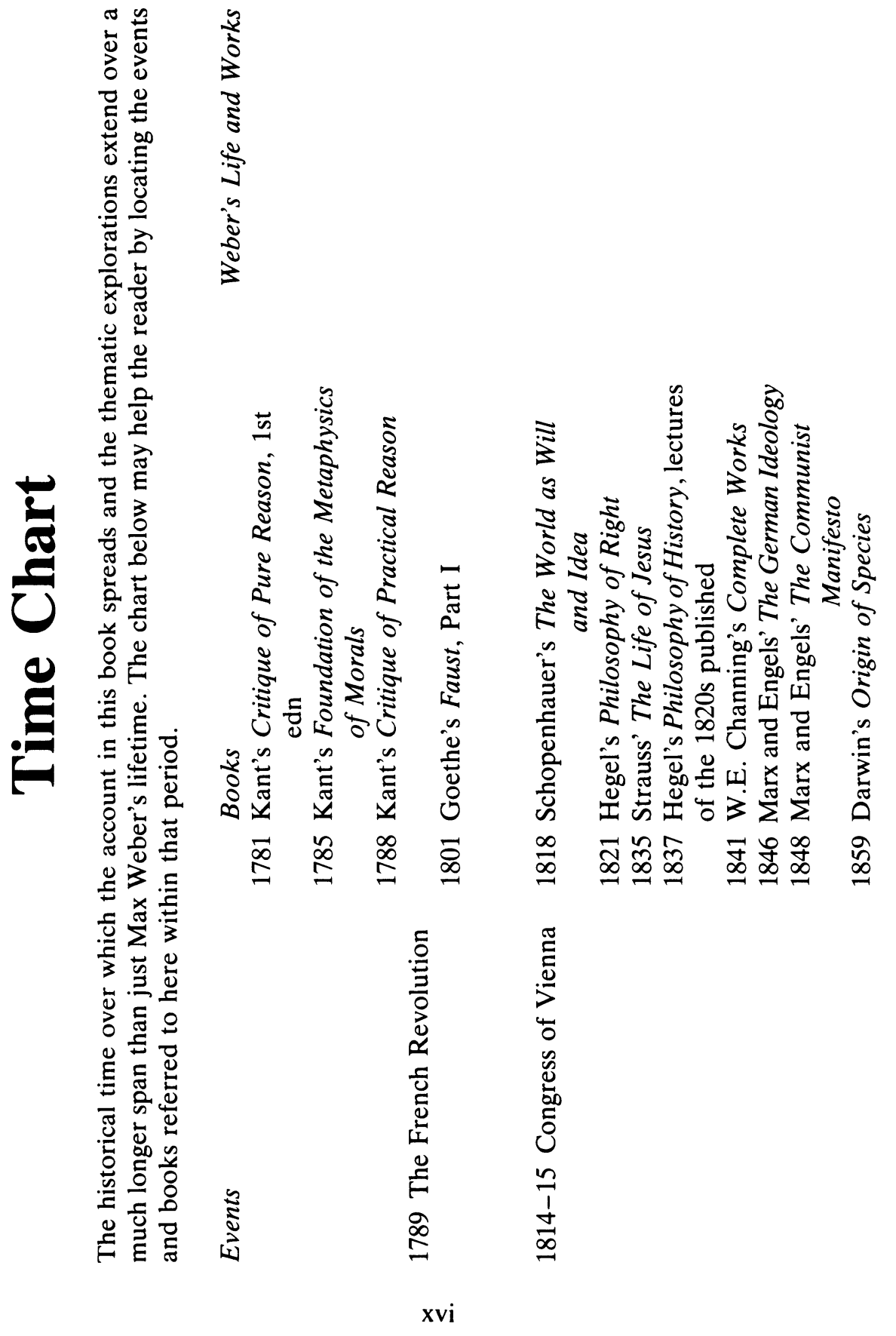



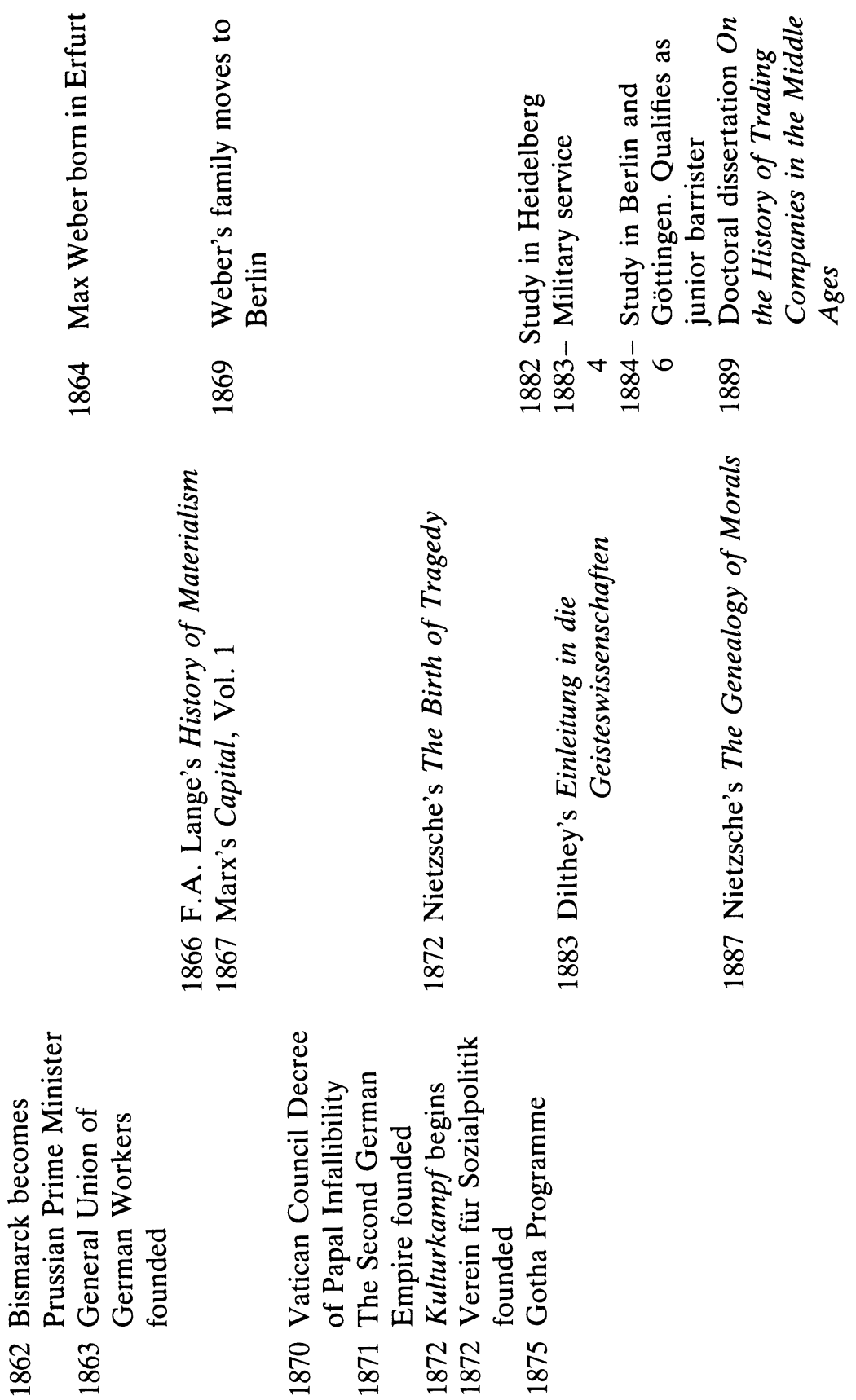

$\stackrel{N}{N} \underset{N}{N} \stackrel{\infty}{\infty}$ 

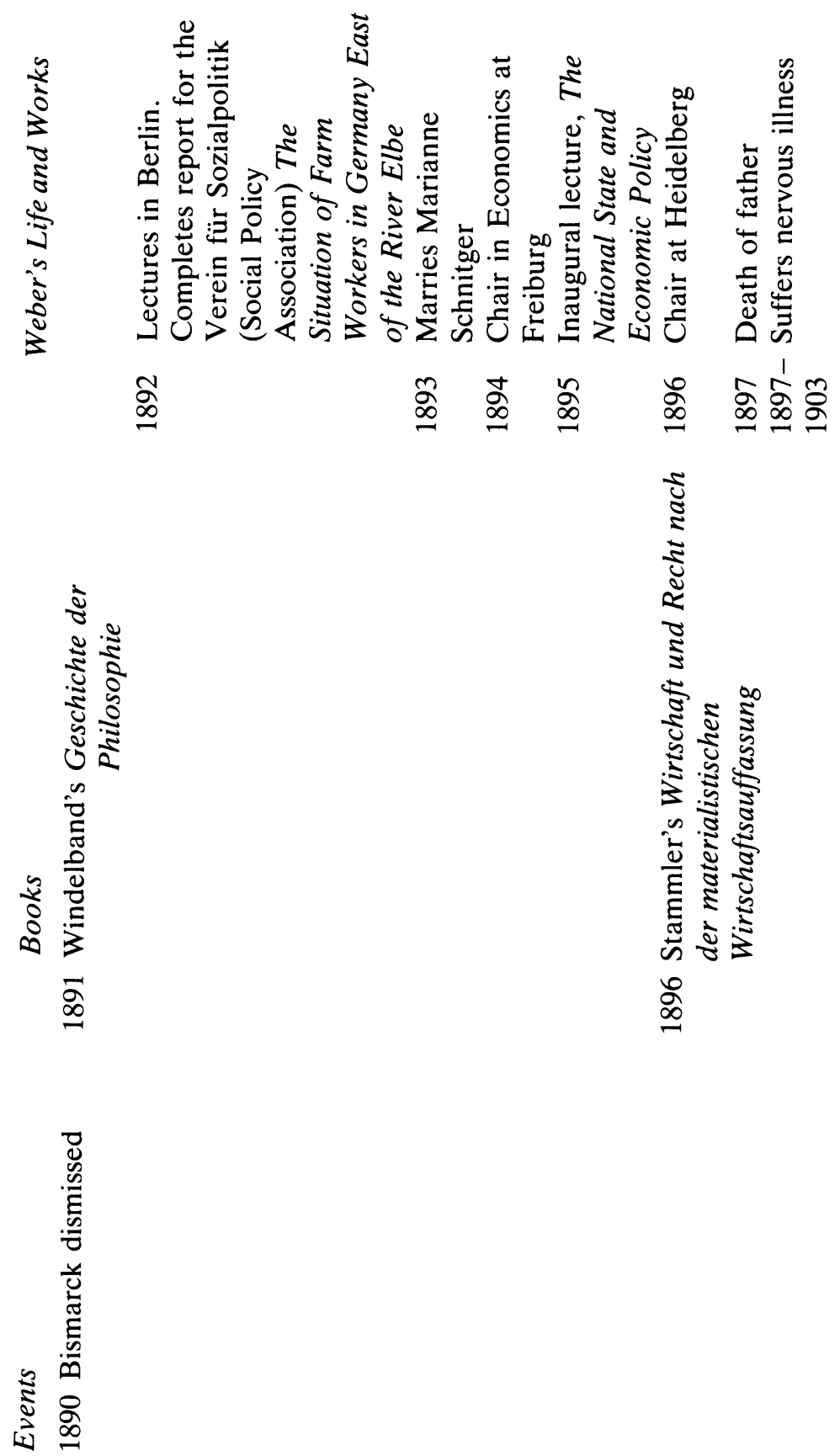


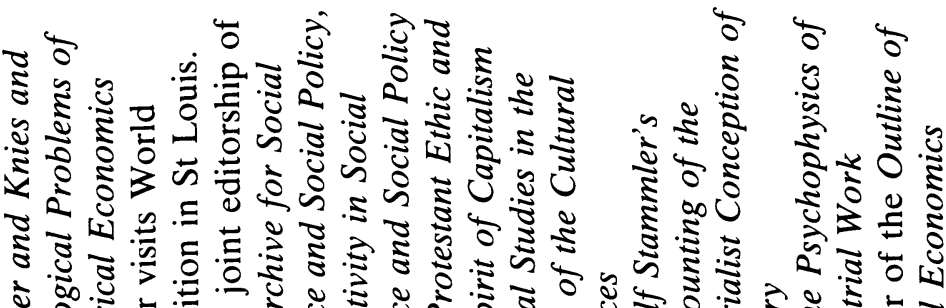

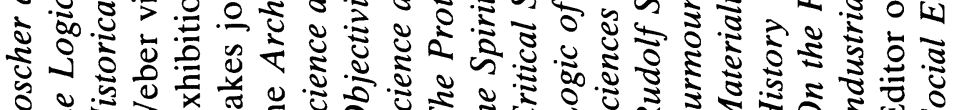

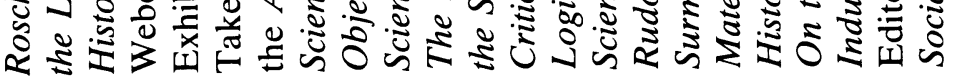
奇
号
ఏ
蜜
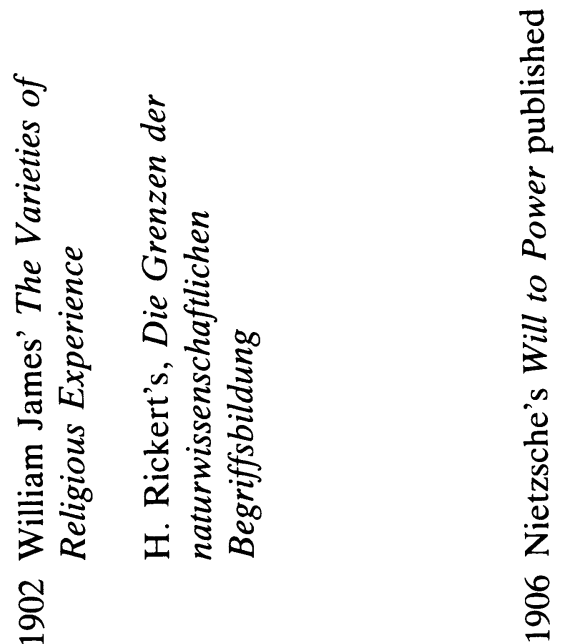

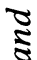

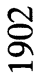

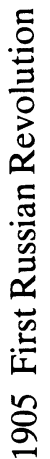

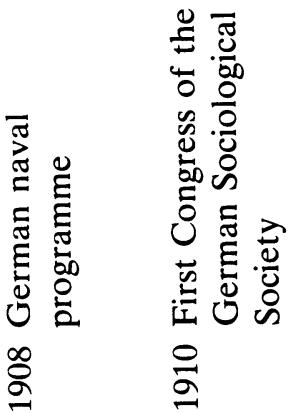




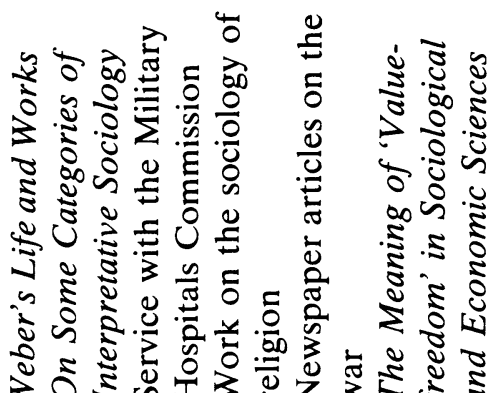

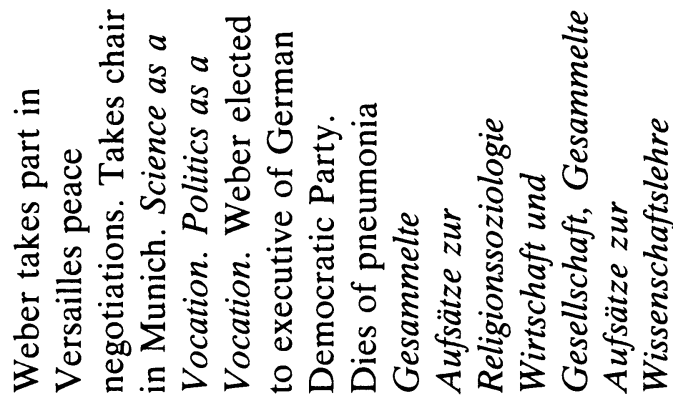

ప
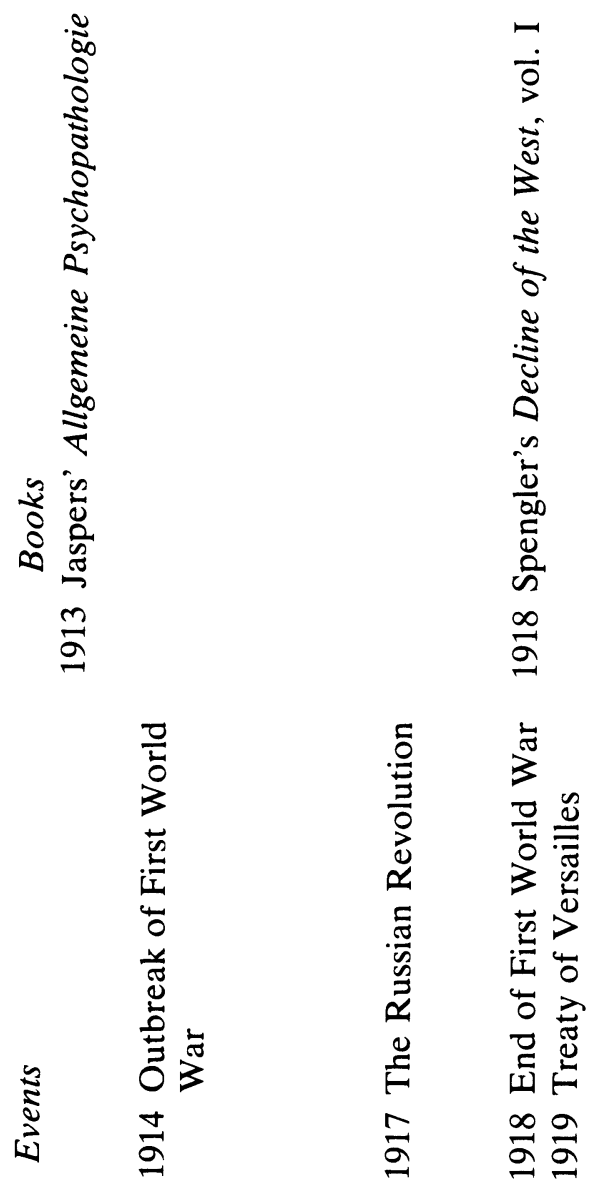
密

薓

文

离

5 $\frac{0}{0} \cdot \frac{0}{N}$

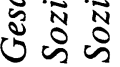

苛
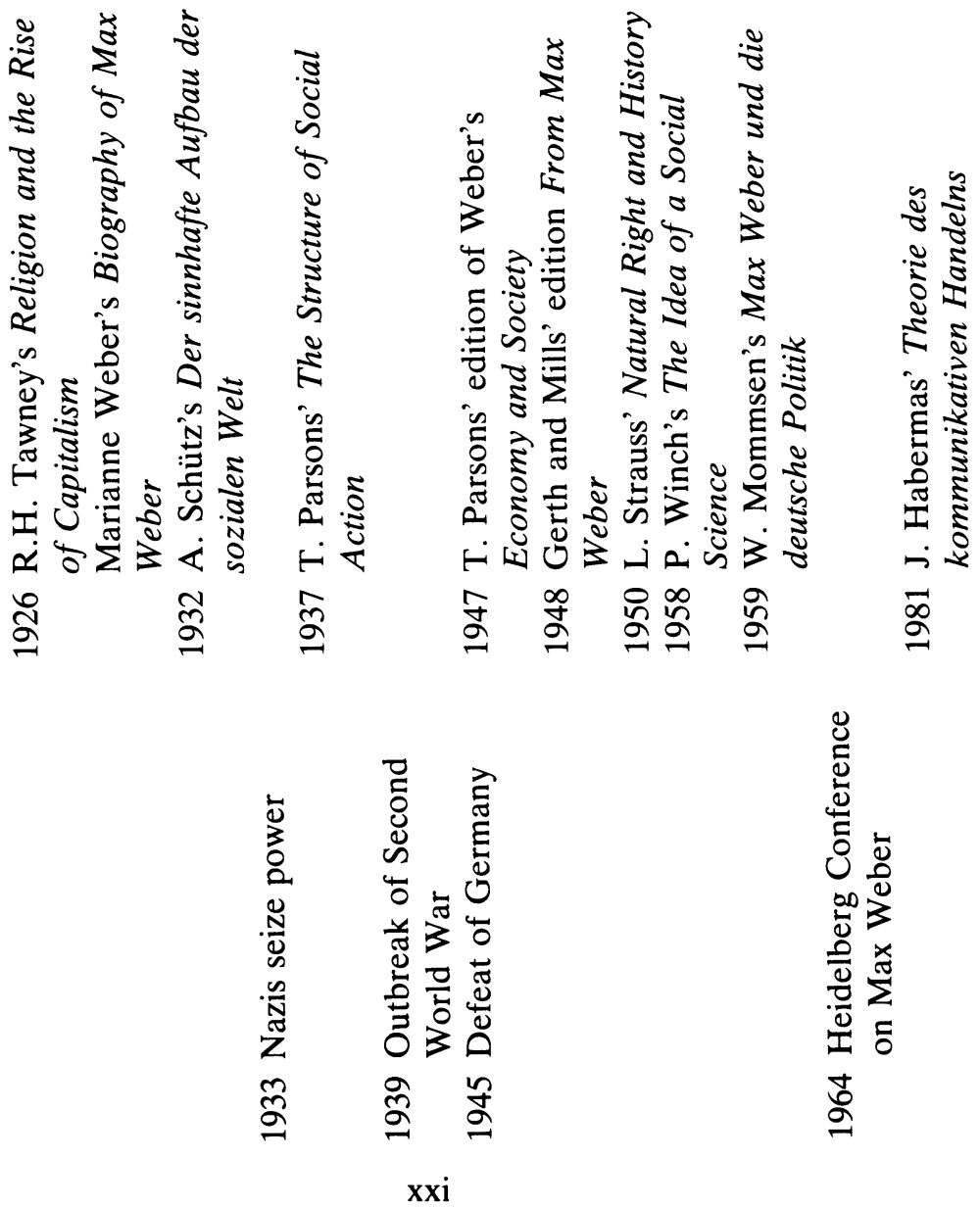